\title{
Genetic variability, heritability, Genetic advance, correlation coefficient and path analysis in gladiolus
}

\author{
${ }^{1}$ Pragnyashree Mishra, ${ }^{2}$ A. K. Singh, ${ }^{3}$ O. P. Singh \\ ${ }^{1}$ Research Scholar, Department of Horticulture, College of Agriculture, G.B.P.U.A.T, Pantnagar \\ U.S.Nagar-263145, U.K. \\ ${ }^{I}$ Department of Horticulture, College of Horticulture and Forestry, N.D.U.A.T, Kumarganj, \\ Faizabad-224229, U.P.
}

\begin{abstract}
Gladiolus (Gladiolus floribundus L.) is a bulbous ornamental plant belongs to family Iridaceae. It is an elegant cut flower grown for its magnificent spikes. The estimates of heritability varied from $99.5 \%$ to $61.1 \%$. The highest heritability estimates in broad sense was observed for the characters vase life (99.5\%) and lowest for height at 30 days after planting. Expected genetic advance expressed as per cent of mean ranged from $18.59 \%$ to $144.78 \%$. The highest of genetic advance as percentage of mean was recorded for number of cormels per plant (144.78\%) and lowest for height at 30 days after planting $(18.59 \%)$. High genetic advance in percentage of mean coupled with high heritability was recorded for the characters number of sprouts, number of spikes per plant, length of spike, vase life, weight of corms per plant, weight of cormels per plant, number of corms per plant, number of cormels per plant provide greater scope for further improvement of these traits in advance generations. Genetic advance ranged from 1.12 to 38.38. The genetic advance is highest for Length of spike (cm) (38.38) and lowest for Number of sprouts (1.12). The PCV were higher than GCV for all the characters taken into consideration. Phenotypic and genotypic coefficient variations were highest for number of spikes per plant (35.76 and 36.25 respectively) and lowest for days to opening of first florets (8.77 and 9.31 respectively). High genetic advance in percentage of mean coupled with high heritability was recorded for the characters number of sprouts, number of spikes per plant, length of spike, vase life, weight of corms per plant, weight of cormels per plant, number of corms per plant, number of cormels per plant.
\end{abstract}

\section{Introduction}

Gladiolus (Gladiolus floribundus L.) is a bulbous ornamental plant belongs to family Iridaceae. It is an elegant cut flower grown for its magnificent spikes. With changing life style and increased urban affluence, floriculture has assumed a definite commercial status in recent times and it has emerged as an important agribusiness venture. In this regard gladiolus has gained much importance as it is the 'Queen of bulbous flowers'. The latin word 'Gladius' means sword and hence, it is often called as 'sword lily' because of the shape of its leaves. Gladiolus was also called 'xiphium' based on the Greek word 'Xiphos' also meaning sword. So we have here what might appear to be pretty war like flower.The crop has wide range of varietal wealth which exhibit a huge range of variability. The present investigation was carried out to find out the extent of genetic variability in the crop by determining the coefficient of variation, heritability and genetic advance, range for different quantitative traits.

\section{Material And Methods}

Fourteen varieties of gladiolus were grown in random block design with three replications during the rabi season 2011-12 at main experimental station, department of Horticulture, NDUA\&T, Kumarganj, which comes under eastern plain zone of Uttar Pradesh. Uniform sized corms of each variety were planted at spacing $40 \mathrm{~cm} \times 20 \mathrm{~cm}$ on plot size of $1.6 \mathrm{~m} \times 1.4 \mathrm{~m}$. Investigation was carried out by considering important fourteen quantitative traits such as, Sprouting per cent, number of sprouts per corm, height at 30 and 60 days after planting, height at harvesting stage, number of leaves per plant, days to opening of first floret, number of spikes per plant, number of florets per spikes, length of spike, vase life, number of corms per plant, number of cormels per plant, weight of corms per plant, weight of cormels per plant.

The standard statistical procedures were followed for calculating genetic constants (Burton and De Vane, 1953). Heritability and genetic advance were determined as per the formulae suggested by Hanson et.al. (1956) and Johnson et.al. (1955) respectively. 
Genetic variability, heritability, Genetic advance, correlation coefficient and path analysis ....

Table 1: Genetic parameters of different quantitative characters of gladiolus varieties

\begin{tabular}{|c|c|c|c|c|c|c|c|c|}
\hline \multirow[t]{2}{*}{ Characters } & \multirow{2}{*}{$\begin{array}{l}\text { Grand } \\
\text { mean }\end{array}$} & \multicolumn{2}{|c|}{ Range } & \multirow{2}{*}{$\begin{array}{l}\text { GCV } \\
(\%)\end{array}$} & \multirow{2}{*}{$\begin{array}{l}\text { PCV } \\
(\%)\end{array}$} & \multirow{2}{*}{$\begin{array}{c}\text { Heritability } \\
\text { (Broad } \\
\text { Sense) \% }\end{array}$} & \multirow{2}{*}{$\begin{array}{l}\text { Genetic } \\
\text { Advance }\end{array}$} & \multirow{2}{*}{$\begin{array}{c}\text { Genetic Advance } \\
\text { as percentage of } \\
\text { mean }\end{array}$} \\
\hline & & Min. & Max. & & & & & \\
\hline Number of sprouts & 1.98 & 1.00 & 1.98 & 28.80 & 30.12 & 91.4 & 1.12 & 56.74 \\
\hline Height at 30 days after planting $(\mathrm{cm})$ & 41.41 & 32.27 & 41.41 & 11.54 & 14.76 & 61.1 & 7.70 & 18.59 \\
\hline Height at 60 days after planting $(\mathrm{cm})$ & 56.96 & 48.37 & 77.23 & 12.10 & 13.83 & 76.6 & 12.44 & 21.83 \\
\hline Height at harvesting stage $(\mathrm{cm})$ & 91.04 & 74.50 & 125.33 & 15.35 & 16.68 & 84.7 & 26.51 & 29.11 \\
\hline Number of leaves per plant & 6.86 & 4.90 & 9.40 & 19.72 & 20.40 & 93.4 & 2.70 & 39.28 \\
\hline Days to opening of $1^{\text {tt }}$ floret (days) & 99.43 & 88.33 & 119.00 & 8.77 & 9.31 & 88.7 & 16.94 & 17.03 \\
\hline Number of spikes per plant & 1.9 & 1.00 & 3.07 & 35.76 & 36.25 & 97.3 & 1.40 & 72.69 \\
\hline Number of floret per spike & 12.23 & 7.57 & 16.23 & 19.61 & 20.24 & 93.9 & 4.78 & 39.16 \\
\hline Length of spike $(\mathrm{cm})$ & 76.07 & 39.97 & 112.63 & 24.72 & 24.96 & 98.1 & 38.38 & 50.45 \\
\hline Vase life(days) & 8.09 & 4.08 & 14.19 & 41.31 & 41.40 & 99.5 & 6.87 & 84.92 \\
\hline Number of corms per plant & 2.00 & 1.00 & 2.73 & 28.69 & 32.01 & 80.3 & 1.05 & 52.98 \\
\hline Number of cormels per plant & 12.00 & 2.07 & 30.87 & 70.56 & 70.84 & 99.2 & 17.37 & 144.78 \\
\hline Weight of corms per plant & 46.51 & 20.92 & 88.46 & 39.21 & 39.84 & 96.8 & 36.98 & 79.51 \\
\hline Weight of cormels per plant & 3.35 & 1.04 & 8.81 & 56.38 & 57.11 & 97.4 & 3.84 & 114.68 \\
\hline
\end{tabular}

Table 2: Genotypic correlation coefficient of number of florets and its quantitative characters of gladiolus

\begin{tabular}{|c|c|c|c|c|c|c|c|c|c|c|c|c|c|c|}
\hline Characters & $\begin{array}{l}\text { No. of } \\
\text { sprouts }\end{array}$ & $\begin{array}{c}\text { Height } \\
\text { at } 30 \\
\text { days } \\
\text { after } \\
\text { planting } \\
\text { (cm) }\end{array}$ & $\begin{array}{c}\text { Height } \\
\text { at } 60 \\
\text { days } \\
\text { after } \\
\text { planting } \\
\text { (cm) }\end{array}$ & $\begin{array}{l}\text { Height at } \\
\text { harvesting } \\
\text { stage }(\mathrm{cm})\end{array}$ & $\begin{array}{c}\text { No. of } \\
\text { leaves } \\
\text { per } \\
\text { plant }\end{array}$ & $\begin{array}{c}\text { Days to } \\
\text { opening } \\
\text { of } 1^{\text {ta }} \\
\text { floret }\end{array}$ & $\begin{array}{l}\text { No. of } \\
\text { spikes } \\
\text { per } \\
\text { plant }\end{array}$ & $\begin{array}{c}\text { Length } \\
\text { of } \\
\text { spike } \\
(\mathrm{cm})\end{array}$ & $\begin{array}{c}\text { Vase } \\
\text { life } \\
\text { (days) }\end{array}$ & $\begin{array}{c}\text { No. of } \\
\text { corms } \\
\text { per } \\
\text { plant }\end{array}$ & $\begin{array}{c}\text { No. of } \\
\text { cormels } \\
\text { per } \\
\text { plant }\end{array}$ & $\begin{array}{l}\text { weight } \\
\text { of } \\
\text { corms } \\
\text { per } \\
\text { plant }\end{array}$ & $\begin{array}{c}\text { weight } \\
\text { of } \\
\text { cormels } \\
\text { per } \\
\text { plant }\end{array}$ & $\begin{array}{l}\text { No. } \\
\text { of } \\
\text { floret } \\
\text { per } \\
\text { spike }\end{array}$ \\
\hline No. of sprouts & - & 0.551 & 0.290 & 0.080 & -0.425 & -0.037 & 0.881 & 0.129 & 0.363 & 0.877 & -0.712 & 0.619 & -0.320 & 0.223 \\
\hline $\begin{array}{l}\text { Height at } 30 \text { days after } \\
\text { planting }(\mathrm{cm})\end{array}$ & & - & 0.542 & 0.484 & -0.127 & -0.127 & 0.495 & 0.401 & 0.235 & 0.318 & -0.341 & 0.470 & 0.124 & -0.187 \\
\hline $\begin{array}{l}\text { Height at } 60 \text { days after } \\
\text { planting }(\mathrm{cm})\end{array}$ & & & - & 0.589 & 0.347 & -0.299 & 0.459 & 0.537 & -0.122 & 0.324 & -0.522 & 0.836 & 0.029 & -0.021 \\
\hline $\begin{array}{l}\text { Height at harvesting stage } \\
(\mathrm{cm})\end{array}$ & & & & - & 0.495 & -0.127 & 0.069 & 0.909 & -0.340 & -0.005 & -0.014 & 0.436 & 0.080 & 0.217 \\
\hline No. of leaves per plant & & & & & - & -0.376 & -0.340 & 0.327 & -0.393 & -0.266 & -0.049 & 0.136 & 0.139 & -0.024 \\
\hline Days to opening of $1^{15}$ floret & & & & & & - & -0.093 & -0.006 & -0.320 & -0.056 & 0.333 & -0.362 & 0.024 & 0.040 \\
\hline No. of spikes per plant & & & & & & & - & 0.219 & 0.470 & 0.828 & -0.607 & 0.680 & -0.059 & -0.061 \\
\hline Length of spike $(\mathrm{cm})$ & & & & & & & & - & -0.094 & 0.092 & 0.031 & 0.456 & 0.231 & -0.073 \\
\hline Vase life(days) & & & & & & & & & - & 0.234 & -0.083 & 0.173 & 0.385 & -0.508 \\
\hline No. of corms per plant & & & & & & & & & & - & -0.631 & 0.643 & -0.223 & 0.376 \\
\hline No. of cormels per plant & & & & & & & & & & & - & -0.565 & 0.590 & -0.150 \\
\hline weight of corms per plant & & & & & & & & & & & & $\cdot$ & -0.030 & 0.162 \\
\hline weight of cormels per plant & & & & & & & & & & & & & - & -0.449 \\
\hline No. of floret per spike & & & & & & & & & & & & & & - \\
\hline
\end{tabular}

\section{Result and Discussion}

The estimates of genotypic coefficient of variation $(\mathrm{GCV})$ and phenotypic coefficient of variation (PCV) for fourteen characters of gladiolus varieties are presented in Table 1.The values of PCV for different characters were higher than corresponding GCV value indicating all the characters under present study were influenced by environmental factors.

It is established that genetic variability is a basic pre requisite for plant breeding programme on which selection acts to evolve superior genotype. Thus the higher the amount of variation present for the various characters in the chosen materials, greater is the scope for its improvement through selection. The genotypic coefficient of variation $(\mathrm{GCV})$ and phenotypic coefficient of variation (PCV) were computed to access the existing variability in the characters. The PCV were higher than GCV for all the characters indicating each and every characters were influenced by environmental factors up to some extent. The greater difference between GCV and PCV were observed for the characters height at 30 days after planting and number of corms per plant indicating that these characters were influenced by environmental factors to greater extent. The very little difference between GCV and PCV were indicated that there was very little environmental influence and these characters cannot improve by providing favorable environment. The above findings are broadly in agreement with the earlier reports (Burton, 1952).

Robinson et al. (1949) viewed that the knowledge of heritability is important to a breeder since it indicates the possibility and extent to which improvement is possible through selection. It is a measure of 
genetic relationship between parents and their offspring. High heritability alone is not enough to make efficient selection in the advanced generations and unless accompanied by substantial amount of genetic advance.

Burton (1952) pointed out that heritability in combination with intensity of selection and amount of variability present in the population influences the genes to be obtained from the selection. Thus genetic advance is another important selection parameter.

Panse (1957) viewed that if a character is governed by non additive gene action it may give high heritability but low genetic advance, whereas, if it is governed by additive gene action heritability and genetic advance would be high. Higher estimates of heritability along with high genetic advance provide good scope for further improvement in advance generation if these characters are subjected to mass progeny and clonal selection.

In the present study the heritability estimates in broad sense were classified into 3 groups such as high $(>75 \%)$, moderate $(60 \%-75 \%)$, low $(<60 \%)$. The high heritability in broad sense were observed for the characters viz. number of sprouts, height at 60 days after planting, height at harvesting stage, number of leaves per plant, days to opening of first floret, number of spikes per plant, length of spike $(\mathrm{cm})$, number of florets per spike, vase life (days), number of corms per plant, number of cormels per plant, weight of corms per plant (g), weight of cormels per plant (g). The moderate heritability in broad sense was observed for height at 30 days after planting.

Genetic advance in percentage of mean give more precise result in comparison to only genetic advance. High genetic advance in percentage of mean coupled with high heritability was recorded for the characters number of sprouts, number of spikes per plant, length of spike, vase life, weight of corms per plant, weight of cormels per plant, number of corms per plant, number of cormels per plant indicating that selection for these characters could be more effective due to additive gene action. Similar work were also reported by Kumar (2010) and Maurya (2011).

The yield, number of spikes per plant is artifact of its various components the identification of important components and information about their inter relationship would be very useful for development of efficient breeding strategies. The breeder should see to access any favorable or unfavorable correlations existing in its materials.

Grafius $(1964, b)$ pointed out there was no way in which yield could be changed without changing one or more of the components. Thus all

Table 4.6: Phenotypic correlation coefficient of number of florets and its quantitative characters of gladiolus

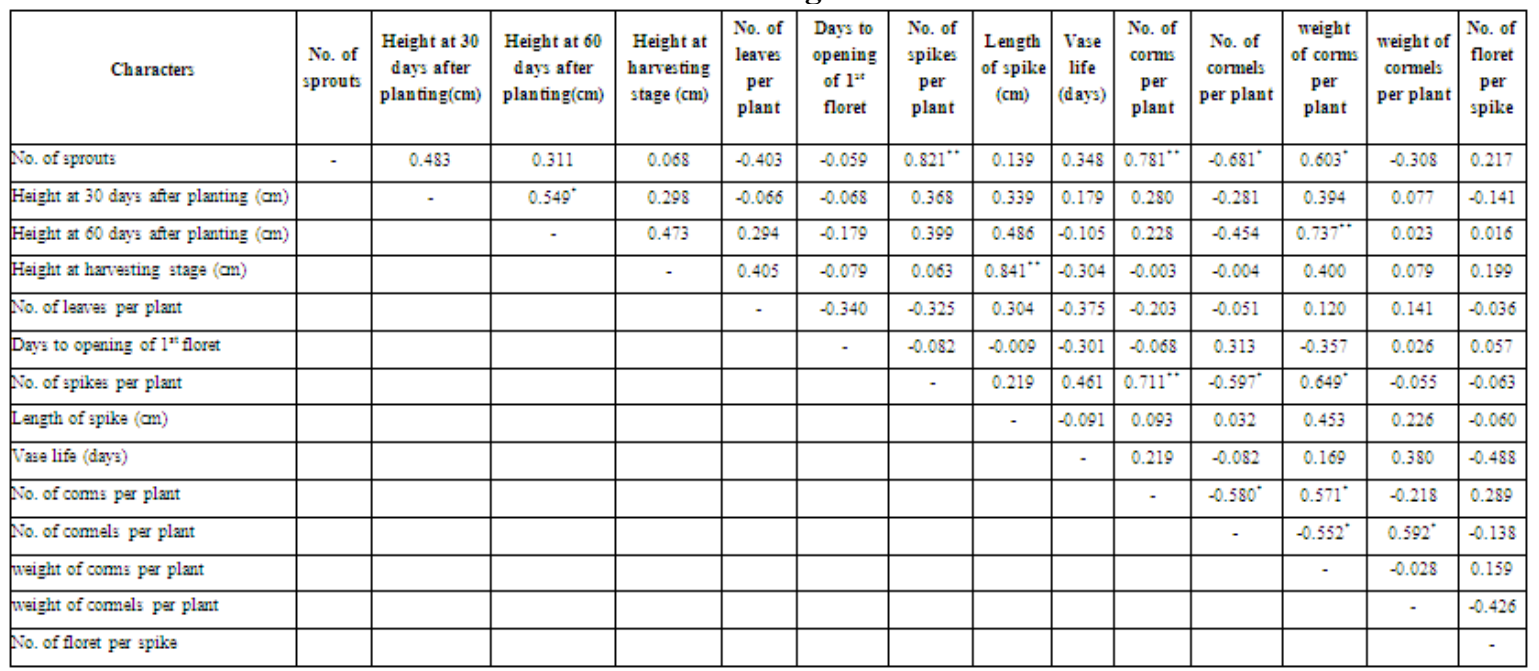

*Significant at probability level 0.05

*** Significant at probability level 0.01

Changes in the yield must be accompanied by changes in one or more of its components. In present study, correlations between fourteen character pairs were worked out in all possible combinations at phenotypic and genotypic level. In general it was observed that genotypic correlation coefficients were found to be higher than corresponding phenotypic correlation coefficient. This indicates a strong inherent association between yield and its component traits. In most of the cases genotypic and phenotypic correlation coefficients were similar in direction.

In present study, number of spikes per plant had positive and significant correlation with number of sprouts, weight of corms per plant, number of corms per plant. Number of spikes per plant had negative and 
significant association with number of cormels per plant. The length of spike registered significant and positive association with height at harvesting stage. Weight of corms per plant was significantly and positively association with number of sprouts per plant, height at 60 days after planting and number of corms per plant and significantly and negatively with number of cormels per plant. Number of cormels per plant is significantly and negatively associated with number of sprouts per plant, number of corms per plant. So the selection for number of spikes per plant the characters viz. number of sprouts, number of corms per plant, weight of corms per plant could contribute considerably. The significant and positive correlations between different characters were previously reported by Sirohi (2000) and Maurya (2011).

\section{References}

[1]. Burton, G.W. (1952).Quantitative inheritance in grasses. Proc. $6^{\text {th }}$ Int. Grasslands Cong. J., 1:227-283.

[2]. Burton, G.W. and De Vane, E.H. (1953). Estimating heritability in tall fescue (Fistvea arundiancea) from replicated clonal material. Agr. J., 45: 284-291.

[3]. Grafius, E.J. (1964 b). A genmetry for plant breeding, Crop Sci.. 4: 241-246.

[4]. Hamson, G.H., Robinson, H.F. and Comstock, R.E. (1956). Biometrica studies of yield in segregating population of Korean lespedeza. Agro. J. 40:260-672.

[5]. Johnson, H.W.; Robinson, H.F. and Comstock, R.E. (1955). Estimates of genetic and environmental variability in soybean. Agron. J., 47: 274-318.

[6]. Kumar, M.; Kumar, V. and Seema (2010). Genetic variability and character association in gladiolus (Gladiolus grandiflorus L.). Environment and Ecology; 28 (1B): 622-628.13ref.

[7]. Maurya, P.K., Kumar R., Chakraborty, B., Rakesh Mer, Mishra, D.S. (2011). Genetic variability and correlation studies in Gladiolus hybrid L. Under tarai condition. Annals of Horticulture; 4 (2): 140-146.

[8]. Sirohi, P.S., Behera, T.K. and Mishra R.L. (2000). Inter-relation among characters and path coefficient studies in gladiolus . Journal of Ornamental Horticulture; New series 3 (1): 30-33. 